Vol. 4: 19-26.

\title{
Lactic acid fermentation of fish offal and chicken by-product with different starter cultures
}

\author{
T. Mikael Lassén
}

Division of Animal Nutrition, Department of Animal Science and Animal Health, Royal Veterinary and Agricultural University, Bülowsvej 13, DK-1870 Frederiksberg C., Denmark

\begin{abstract}
Lactic acid fermentation was evaluated as a method to preserve fish and chicken by-products. Herring (Clupea harengus) by-products (viscera and heads) and chicken by-products (heads, viscera, feathers, feet and discarded whole chickens) were minced, mixed with 5\% dextrose and inoculated with $10^{8}$ colony forming units ( $\left.\mathrm{cfu}\right) / \mathrm{g}$ of four different lactic acid bacteria cultures. The by-product was fermented at $25^{\circ} \mathrm{C}$ and evaluated for $\mathrm{pH}, \%$ produced lactic acid, redox potential and odour during four weeks's storage. In herring offal, $\mathrm{pH}$ decreased from 6.8 to 4.2 in one week and stabilized at about 4.3 . In the same time, $2.0 \%$ to $3.2 \%$ lactic acid was produced and concentrations stabilized from $2.5 \%$ to $4.0 \%$. In chicken offal, $\mathrm{pH}$ decreased to a stable level of 4.4 , and $3.2 \%$ lactic acid was produced after one week of fermentation. A negative and stable redox potential was achieved after one week of fermentation in both herring and chicken offal.
\end{abstract}

Key words: animal waste, silage, lactic acid bacteria, redox potential, mink feed

\section{Introduction}

Animal by-products are obtained in feed plants (pet food and fur animal feed) in which the raw material is processed in different ways, depending on the origin and destination of the feed. The most common processing methods are heating, drying, chilling and freezing.

The increasing cost of energy has aroused interest in developing alternative storage methods. Promising results have been obtained in preserving fish and slaughter-house by-products with lactic acid bacteria (LAB) (Kangas and Kangas 1983, Lindgren and Pleje 1983, Hassan and Heath 1986, Tibbets et al. 1987, Skrede and Nes 1988, Russel et al. 1992, Urlings 1992). Fermented silage is a product of a controlled fermentation process in which production of lactic acid (LA) results in a pH below 4.5. Owing to the lack of fermentable carbohydrates and a natural LAB flora, animal by-products cannot be subjected to lactic acid fermentation without the addition of a substrate. The methods used 


\section{AGRICULTURAL SCIENCE IN FINLAND}

Lassén, T. M.: Lactic acid fermentation of fish offal and chicken by-product with different starter cultures

are based on the addition of LAB and fermentable carbohydrates to minced animal by-products.

The preservative action of LAB in animal byproducts is caused by low $\mathrm{pH}$, a substantial amount of undissociated organic molecules, the buffering capacity of the raw material, hydrogen peroxide production, competition with other bacteria for nutrients, production of antibiotics and bacteriocines (bacteriocines are most often bacteriostatic to closely related species) and decreased redox potential (Raccach and Baker 1978, Smith and Palumbo 1981). The lowering in $\mathrm{pH}$ and the effect of undissociated LA inhibit growth of bacteria such as Staphylococcus (Bartholomew and Blumer 1980), Escherichia coli (Tramer 1966), Serratia, Enterobacter, Citrobacter, Achromobacter and Pseudomonas (Dubois et al. 1979).

Bacteria strains commonly used as starter cultures are Lactobacillus plantarum (Kangas and Kangas 1983, Lindgren and Pleje 1983, Skrede and Nes 1988, Urlings 1992), Pedioccocus acidilactici (Lindgren and Pleje 1983), Lactobacillus acidophilus (Tibbets et al. 1987) and some not fully characterized commercial cultures (Pelzyme ${ }^{\circledR}$, Lassén et al. 1990a, b, PSI ${ }^{\circledR}$, Russel et al. 1992, Stabisil ${ }^{\circledR}$, Partanen et al. 1992). With a suitable starter culture, a mixture of fish or slaughter by-products and carbohydrates may reach a pH of 4.4 to 5.0 in 24 to $48 \mathrm{~h}$ (Lindgren and Pleje 1983). Silage of this kind has been used as a component of feed for furbearing animals (Skrede and Nes 1988, Lassén et al. 1990a, b, Urlings 1992) and pigs (Tibbets et al. 1987, Partanen et al. 1992) with varying results.

LAB fermentation of animal by-products may be worth developing as an alternative storage method, due to its economic advantages and its potential to kill pathogens (Wooley et al. 1981). To produce a quality feed product, the conditions for production from various raw materials have to be systematically evaluated, and efficient methods for quality control of the product developed. This paper examines the conditions for fermentating herring and chicken offal.

\section{Material and methods}

Fish offal was fermented at the Royal Veterinary and Agricultural University, Denmark and chicken offal at FinnEwos Agri, Kariniemi, Finland.

Fish offal (viscera and heads) from herring (Clupea harengus) caught in the North Sea in autum was obtained from Gilleleje Processing Plant, Gilleleje, Denmark. The offal was minced coarsely once through a $10-\mathrm{mm}$ plate and deepfrozen within $6 \mathrm{~h}$. The offal was kept at $-20^{\circ} \mathrm{C}$ until $12 \mathrm{~h}$ before it was to be used. All fermentations were conducted using thawed herring offal, that had been mixed thoroughly in a Varimixer bakery machine and incubated at $25^{\circ} \mathrm{C}$. Fermentation was conducted with commercial starter cultures containing Lactobacillus plantarum (L.p), Lactobacillus plantarum: Pediococcus pentosaceus (L.p:P.p 1:2), Lactobacillus plantarum:Pediococcus acidilactici (L.p:P.a 1:2) (Chr. Hansen's Lab. A/S, Hørsholm, Denmark), and the commercial Pelzyme ${ }^{\circledR}$ (Cultor Ltd., Feed Division, Helsinki, Finland). The herring offal was fermented for one week in 3-kg portions with $5 \%(\mathrm{w} / \mathrm{w})$ dextrose added and an initial inoculum of $10^{8}$ colony forming units $(\mathrm{cfu}) / \mathrm{g}$ in 51 plastic containers equipped with a water airlock. After fermentation the material was stored at $25^{\circ} \mathrm{C}$ for four weeks.

Chicken by-products were obtained from 39 day-old chickens and processed at the chicken slaughterhouse as follows. Immediately after slaughter of the chickens by-products (heads, viscera, feet and discarded whole chickens) were minced through a $10-\mathrm{mm}$ plate, homogenized through a $6-\mathrm{mm}$ plate and mixed with $12 \%(\mathrm{w} /$ w) extruded wheatmeal and feathers $(2: 1)$ according to the FinnEwos Agri method ${ }^{\circledR} ; 5 \%$ dextrose was then added. Finally, the starter culture was added when the material to be fermented had reached a temperature of $25^{\circ} \mathrm{C}$. The same starter cultures were used as for fermentation of herring offal, with an initial inoculum of $10^{8} \mathrm{cfu} / \mathrm{g}$. All fermentations were conducted in triplicate at $25^{\circ} \mathrm{C}$ in the same types of plastic container as 
Vol. 4: 19-26.

used for herring offal. The fermented material was stored at $25^{\circ} \mathrm{C}$ for four weeks.

Treatment effects were evaluated by monitoring the $\mathrm{pH}$ values, LA production and changes in redox potential during four weeks of storage as previously described (Lassén 1995a). All three samples from each batch were analysed weekly for $\mathrm{pH}$ and LA production, and since earlier experiments (Lassén 1995a) had yielded very stable and reproducible results within treatments and time, only one sample per batch was measured for redox potential.

Proximate analysis of herring and chicken offal before and after fermentation was conducted according to standard methods. The dry matter content was analysed by drying $4 \mathrm{~g}$ samples in a forced draught oven at $60^{\circ} \mathrm{C}$ for $18 \mathrm{~h}$. Nitrogen was determined by the Kjeldahl procedure and protein calculated as $\mathrm{N} \times 6.25$. Fat was hydrolysed with $\mathrm{HCl}$, extracted with petroleum ether and analysed by the Soxtec method. Soluble and hydrolysable hexose carbohydrates (dextrose) were analysed according to Jacobsen (1981).

Statistical analyses were performed according to the GLM procedure in SAS (SAS 1985). Changes in $\mathrm{pH}$ and LA production were evaluated separately for the fermentation of herring offal and chicken waste (1) and for the materials together (2) according to the following splitplot design model:

$\mathrm{Yi}_{j k}=\mu+\mathrm{a}_{i}+\mathrm{b}_{j}+\mathrm{c}(\mathrm{i})+(\mathrm{ab})_{i j}+\varepsilon_{i j k}$

where,

$\mathrm{Y}_{i j k}=$ the ijk th observation,

$\mu=$ general mean,

$\mathrm{a}_{i}=$ fixed effect of starter culture,

$i=1-4$ (1) or material, $i=1$ or 2 (2),

$\mathrm{b}_{j}=$ fixed effect of storage time , $j=0,1,2,3$ and 4 weeks ( 1 and 2),

(ab) $i j=$ interaction effect between starter culture,

$i=1-4(1)$, or material $i=1$ or 2 (2) and storage time, $0-4$ weeks ( 1 and 2),

$\mathrm{c}(i)=$ random sample within starter culture (1)

or material (2),

$\varepsilon_{i j k}=$ random error.
Table 1. LA-production and changes in $\mathrm{pH}$ in herring offal fermented with different starter cultures, $10^{8} \mathrm{cfu} / \mathrm{g}$, and $5 \%$ dextrose, and chicken offal fermented with $5 \%$ dextrose and $12 \%$ extruded wheatmeal:feathers $(2.1)$ and $10^{8} \mathrm{cfu} / \mathrm{g}$ at $25^{\circ} \mathrm{C}$.

$\mathrm{pH}$ $\%$ LA

Storage time, Herring Chicken Herring Chicken weeks

\begin{tabular}{lllll}
\hline 0 & 6.8 & 6.2 & 0.0 & 0.0 \\
1 & 4.3 & 4.5 & $2.3^{\mathrm{a}}$ & $3.2^{\mathrm{b}}$ \\
2 & 4.1 & 4.3 & $2.8^{\mathrm{a}}$ & $4.1^{\mathrm{b}}$ \\
3 & & & & \\
4 & 4.2 & 4.4 & $2.8^{\mathrm{a}}$ & $4.1^{\mathrm{b}}$ \\
\hline
\end{tabular}

a b Values differ significantly $(\mathrm{P}<0.01)$.

$\mathrm{LA}=$ Lactic acid

$\mathrm{cfu}=$ colony forming units

Treatment effect were tested against the silo effect, thus using silos within starter culture (1) or material (2) as an error term.

\section{Results}

Fermentation of herring offal with $5 \%$ dextrose at $25^{\circ} \mathrm{C}$ resulted in a drop in $\mathrm{pH}$ from 6.8 to 4.3 (L.p) and from 6.8 to 4.0 (Pelzyme ${ }^{\odot}$ ), in one week; pH stabilized at between 3.9 and 4.5 after four weeks (Table 1). Rapid LA production was observed during the first week of fermentation, which stabilized at between $2 \%$ and $4 \%$ after four weeks of storage (Fig. 1a). The effect on redox potential showed a similar pattern, Pelzyme ${ }^{\circledast}$ having the most negative redox potential after four weeks (Fig. 1b).

Chicken offal was fermented successfully. Fermentation with $5 \%$ dextrose and $12 \%$ extruded wheatmeal:feathers (2:1) resulted in rapid LA production $(2.8 \%$ to $3.2 \%)$, and a $\mathrm{pH}$ drop from 6.2 to 4.4 in one week (Fig. 2a), followed by a negative redox potential (Fig. 2b). Pelzyme ${ }^{\circledR}$ resulted in a highly significant $\mathrm{pH}$ decrease 


\section{AGRICULTURAL SCIENCE IN FINLAND}

Lassén, T. M.: Lactic acid fermentation of fish offal and chicken by-product with different starter cultures

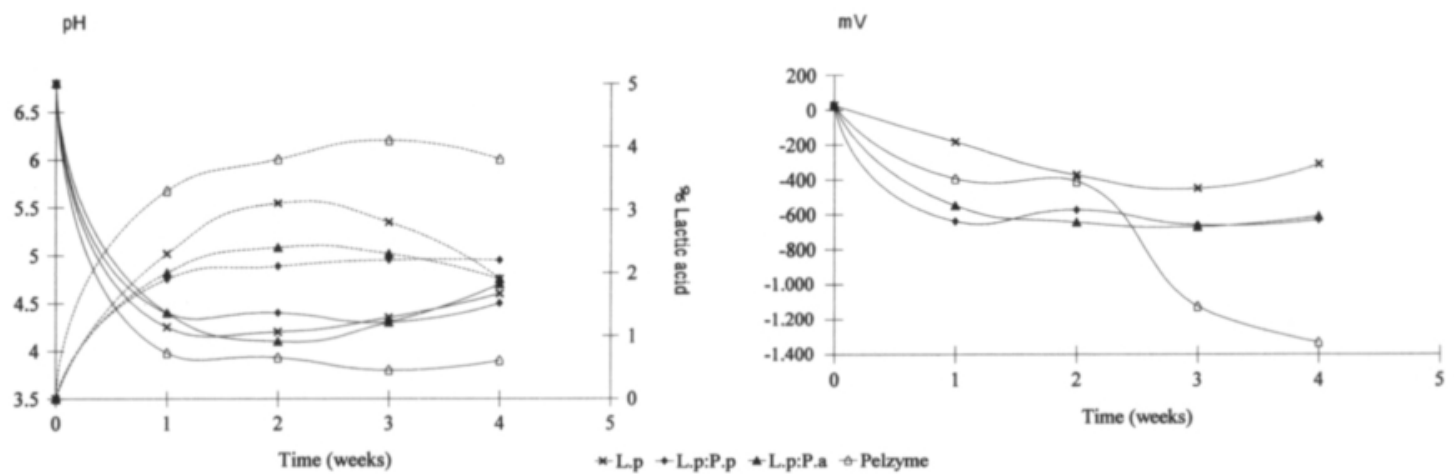

Fig. 1. Lactic acid fermentation of herring offal with different LAB cultures, $10^{8}$ colony forming units $/ \mathrm{g}$ and $5 \%$ dextrose at $25^{\circ} \mathrm{C}$. a) - Changes in $\mathrm{pH},-\%$ LA. b) - Changes in redox potential.

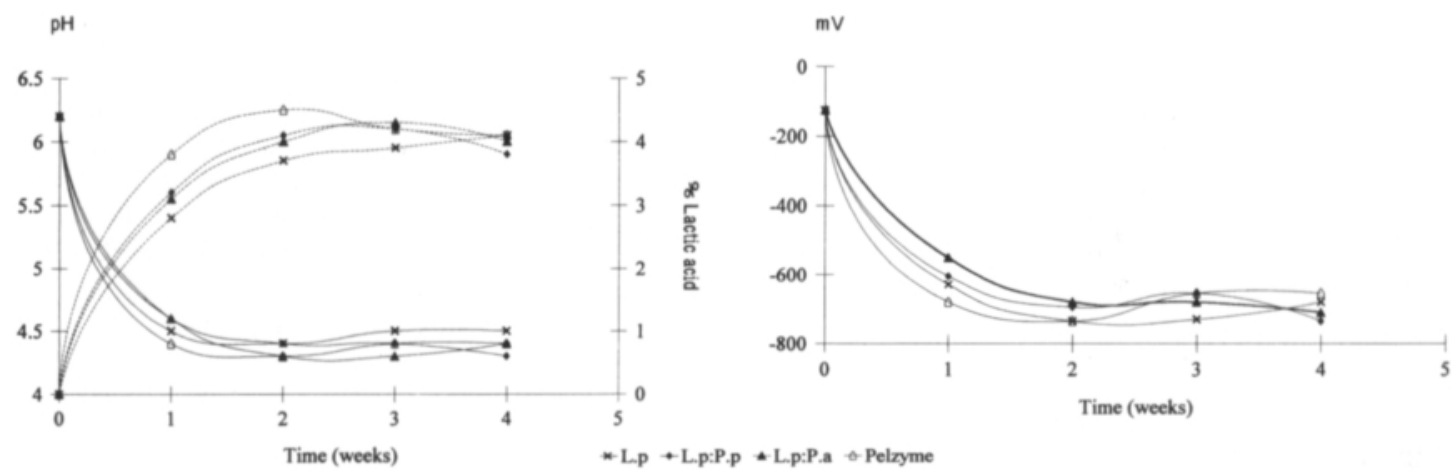

Fig. 2. Fermentation of chicken offal with different LAB cultures, $10^{8}$ colony forming units/g, $5 \%$ dextrose and $12 \%$ extruded wheatmeal:feathers $(2: 1)$ at $25^{\circ} \mathrm{C}$. a) —Changes in $\mathrm{pH},-\%$ LA. b) - Changes in redox potential.

$(\mathrm{P}<0.01)$ during the first week of fermentation, followed by stabilization at about $\mathrm{pH}$ 3.9. The other cultures tested were initially slower than Pelzyme ${ }^{\circledR}$, but still showed a highly significant LA production and $\mathrm{pH}$ decrease after two weeks' storage. The difference in $\mathrm{pH}$ and LA production between the LAB cultures tested and Pelzyme $^{\oplus}$ was significant $(\mathrm{P}<0.01)$ when herring offal was fermented, but no significance was noted between LAB cultures when chicken offal was used. Eventually a highly significant $(p<0.01)$ difference in LA production between different materials was found for all cultures used in the present study; the $\mathrm{pH}$ decrease was, however, nonsignificant (Table 1).

The freshly minced herring had the texture and appearance of coarsely minced fish, where- as the fermented offal was liquefied and had a clear layer of oil on the top. Chicken offal did not liquefy as much as herring offal during storage. In fermented herring and chicken offal the protein content in dry matter basis increased after fermentation for one week. The offal did not contain fermentable carbohydrates before addition of 5\% dextrose (herring offal) and $12 \%$ extruded wheatmeal:feathers $(2: 1)$ and 5\% dextrose (chicken offal), and only low concentrations $(0.6 \%$ and $3.2 \%)$ remained after fermentation (Table 2).

Conversion of dextrose/carbohydrates to LA was more effective in chicken offal than in herring offal (Fig. 3). In fermented herring offal, the decrease in dextrose did not, however, correspond with LA production, and only $40 \%$ to 
Vol. 4: 19-26.

Table 2. Proximate composition of herring and chicken offal before and after fermentation for one week at $25^{\circ} \mathrm{C}$.

\begin{tabular}{lccccc}
\hline Offal & $\begin{array}{c}\text { DM } \\
\%\end{array}$ & $\begin{array}{c}\text { Fat } \\
\text { \% of DM }\end{array}$ & $\begin{array}{c}\text { Protein } \\
\text { \% of DM }\end{array}$ & $\begin{array}{c}\text { Sugar } \\
\text { \% of DM }\end{array}$ & $\begin{array}{c}\text { Starch } \\
\text { \% of DM }\end{array}$ \\
\hline Herring $^{\mathrm{a}}$ & 29.3 & 38.6 & 35.4 & 14.6 & 0.0 \\
Fermented herring $_{\text {Chicken }^{\mathrm{b}}}$ & 22.2 & 26.7 & 40.8 & 4.4 & 0.0 \\
Fermented chicken $^{2}$ & 39.6 & 22.2 & 36.1 & 14.9 & 12.1 \\
\hline
\end{tabular}

a Herring offal, $5 \%$ dextrose, and $10^{8} \mathrm{cfu} / \mathrm{g}$ Lactobacillus plantarum

${ }^{b}$ Chicken offal, $5 \%$ dextrose, $12 \%$ extruded wheatmeal:feathers $(2: 1)$, and $10^{\circ} \mathrm{cfu} / \mathrm{g}$ Lactobacillus plantarum $\mathrm{cfu}=$ colony forming units

$45 \%$ of the dextrose was metabolized to LA with the Lactobacillus plantarum-based cultures tested. Mainly in herring offal, when Pelzyme ${ }^{\circledR}$ was used as starter culture, the conversion of dextrose to LA was $80 \%$ complete, and consequently more acid was produced (Fig. 1a).

\section{Discussion}

Fast fermentation of herring offal with a rapid drop in $\mathrm{pH}$ to 4.4 or less resulted in a less putrefactive odour and a more stable silage than in silages produced at slower $\mathrm{pH}$ declines. In the literature, a preserving $\mathrm{pH}$ has been reported to occur after 24-72 h (Mackie et al. 1971, Raa 1980, Lindgren and Pleje 1983, Hassan and Heath 1986, Lassén et al. 1990a, b). Usually, a higher amount of lactic acid has to be produced in fish silage to yield a properly fermented product than in grass silage and silage from slaughter-house wastes. Lindgren and Pleje (1983) found that the LA content giving a pH below 4.4 was above $4.0 \%$ in fish silage, about $3.0 \%$ in slaughter-house wastes and below $2.0 \%$ in grass silage. Hassan and Heath (1986) reported that $4.4 \%$ LA was needed to obtain a pH of 4.2 in fish silage fermented with $5 \%$ lactose as the carbohydrate source. In the present study with its different starter cultures, $2.7 \%$ (L.p), $2.3 \%$ (L.p:P.p), $2.5 \%$ (L.p:P.a), and 2.5\% (Pelzyme ${ }^{\circledast}$ )

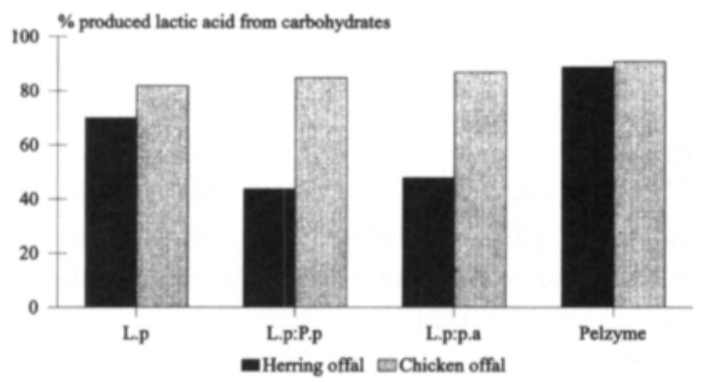

Fig. 3. LA production from $5 \%$ dextrose for different LAB cultures $\left(10^{8}\right.$ colony forming units/g) in silage made from herring and from $5 \%$ dextrose and $12 \%$ extruded wheatmeal:feathers (2:1)) in silage made from chicken offal at $25^{\circ} \mathrm{C}$.

LA were needed to obtain a pH below 4.2 , and $1.8 \% \mathrm{LA}$ in fish silage resulted in a $\mathrm{pH}$ below 4.4 , all concentrations being below the concentrations reported in the literature. Successful fermentation of chicken offal was characterized by a higher initial lactic acid production to obtain a pH below 4.5 ; thus owing to its higher bone content, chicken offal is likely to have a higher buffering capacity than herring offal. After three weeks' storage a minor drop in LA content was observed, possibly due to the hydrolysis of bone material, neutralizing the acid. This may also be followed by an accumulation of biogenic amines (Lassén 1995b), which also neutralized the material. A high LA concentration at $\mathrm{pH} 4.3$ gives a high concentration of undissociated LA molecules; these provide the antimicrobial effect but 


\section{Lassén, T. M.: Lactic acid fermentation of fish offal and chicken by-product with different starter cultures}

also inhibit further growth of LAB (Baird-Parker 1980).

Measurements of redox potential may be used to evaluate the growth conditions of anaerobic bacteria (Wolstrup 1972) and to determine the oxygen content of biological material (Harrison 1971). Lactobacilli are generally anaerobic to microaerophilic, demanding negative redox potentials, but certain strains grow aerobically and may lower the $\mathrm{pH}$ even under aerobic conditions (Kandler and Weiss 1986). Redox potential is always positive in the muscle and negative in the viscera of freshly caught herring (Huss and Larsen 1979). The redox potential in warmblooded animals attains a negative value shortly after the animals have been slaughted and remains negative until aerobic deterioration sets in (Barnes and Ingram 1955, Wirth and Leistner 1970). Rapid establishment of the LAB is important for LA production and the decrease in $\mathrm{pH}$ and redox potential. If the material reaches a low redox potential in a short time, growth of anaerobic bacteria, usually of the genera $\mathrm{Al}$ teromonas, is inhibited. These bacteria are implicated in the spoilage of North Sea fish (Shewan 1977). Other bacteria of the genus Salmonella are also known to be inhibited by a low redox potential (Chung and Goepfert 1970). Here, a low redox potential $(-330 \mathrm{mV}$ to -680 $\mathrm{mV}$ ) was achieved after one week of fermentation, the level being somewhat lower for silage of herring offal than for silage of chicken offal. The results of this and an earlier study (Lassén 1995a) clearly show that appropriate fermentation leads to a low and stable redox potential, whereas inappropriate fermentation leads to an increasing redox potential and $\mathrm{pH}$ as a result of decreased LA concentration.

The more efficient use of dextrose as a car- bohydrate source when chicken offal was fermented might be explained by the lower number of actively competing bacteria. Bacteria in chicken have optimal growth conditions at about $30^{\circ} \mathrm{C}$ to $37^{\circ} \mathrm{C}$, but fish bacteria are more active at lower temperatures $\left(15^{\circ}-25^{\circ} \mathrm{C}\right)$ and compete with $\mathrm{LAB}$ for free dextrose (Jay 1986). The changes recorded in chemical content after fermentation were probably due to separation processes in the material, and were therefore considered not to reflect true changes in chemical composition as an effect of the fermentation process. The decreased fat content in dry matter after fermentation might be explained by the separation process, in which the fat fraction is situated on top of the silo and the sample is taken from the bottom of the silo.

The result of this study suggest that animal by-products can be fermented with $5 \%$ dextrose and $10^{8} \mathrm{cfu} \mathrm{LAB} / \mathrm{g}$ at $25^{\circ} \mathrm{C}$, and that fermentation is thus a viable alternative to current offal handling practices. Successful fermentation depends, however, on the hygienic quality of the raw material and good hygiene at the processing plant. To improve the process, there is still a need for development of better starter cultures and methods for determining product quality.

Acknowledgements. Financial support was provided by the Academy of Finland. My sincere gratitude is due to Mrs Birthe Jessen of Chr. Hansen's Lab., A/S, Hørsholm, Denmark, for providing the starter cultures and for her valuable suggestions on which cultures to use, to Mr Matti Laitinen of Cultor Ltd, Helsinki, Finland and to Mr Karl-Erik Forsman of FinnEwos Agri, Vaasa, Finland, for assistance with chicken offal fermentation, to Associate Professor Anne-Helene Tauson for constructive criticism, and for her skilful help with statistical analysis, and to Associate Professor Niels Enggaard Hansen for valuable suggestions and comments.

\section{References}

Baird-Parker, A. C. 1980. Organic Acids. In: Silliker, J. H. (ed.). Microbial Ecology of Foods. Vol. 1. Academic Press, London. p. 126-135.

Barnes, E. M. \& Ingram, M. 1955. Changes in the oxi- dation-reduction potential of the sterno-cephalicus muscle of the horse after death in relation to the development of bacteria. Journal of the Science of Food and Agriculture 6: 448-455. 
Vol. 4: 19-26.

Bartholomew, D. T. \& Blumer, T. N. 1980. Inhibition of Staphylococcus by lactic acid bacteria in country-style hams. Journal of Food Science 45: 448-455.

Chung, K. C. \& Goepfert, J. M. 1970. Growth of Salmonella at Low pH. Journal of Food Science 35: 326-328. Dubois, G., Beaumier, H. \& Charbonneau, R. 1979. Inhibition of bacteria isolated from ground meat by Streptococcaceae and Lactobacillaceae. Journal of Food Science 44: 1649-1652.

Harrison, D. E. F. 1971. Abstracts from Fift International Symposium and study Group on continuous culture of Microorganisms. Oxford. $39 \mathrm{p}$.

Hassan, T. L. \& Heath, J. L. 1986. Biological fermentation of fish waste for potential use in animal and poultry feeds. Agricultural Wastes, 15: 1-15.

Huss, H. H. \& Larsen, A. 1979. The post mortem changes in the oxidation-reduction potential of fish muscle and internal organs. In: Sobolenska-Ceronik, S. K. et al. (eds.). Food as an Ecological Environment for Pathogenic and Index Organism. Proceedings of the 10th International Symposium of IAMS (International Association of Microbial Societies), Ars, Poland. p. 265-279.

Jacobsen, E. E. 1981. Sukker og stivelse (LHK) -ny analysemetode. Biotechnological Institute, Kolding, Denmark. Beretning 98. $16 \mathrm{p}$.

Jay, J. M. 1986. Modern Food Microbiology. Third edition, Van Nostrand, C.O., New York, 622 p.

Kandler, O. \& Weiss, N. 1986. Regular, Nonsporing Gram-positive Rods. Genus Lactobacillus. In: Sneath, P. H. A. et al. (eds.). Bergey's Manual of Systematic Bacteriology, Vol. 2. Williams \& Wilkins Co., Baltimore. p. 12081234.

Kangas, J. \& Kangas, A. L. 1983. Biologisk konservering av pălsdjursfoder. Finsk Pălstidskrift 17: 333-338.

Lassén, T. M. 1995a. Evaluation of conditions for fermentation of fish offal. Agricultural Science in Finland 4: 11-17.

- 1995b. Biological quality of fermented fish offal and chicken by-product. Agricultural Science in Finland 4:2733.

-, Hildén, A., Hildén, B. H. \& Laitinen, M. J. 1990a. Praktisk tillămpning av erfarenheter från försök med biologisk konserverad ensilage i foder till mink och răv. NJFUtredning/Rapport Nr. 60. 20 p.

-, Hillemann, G. \& Fors, F. 1990b. Fisk- och slaktavfall konserverad med mjölksyrabakterie- och enzympreparaten Pelzyme $\circledast$ och Marisil® i foder till pălsdjur. NJFUtredning/ Rapport Nr. 60. 9 p. Poster.

Lindgren, S. E. \& Pleje, M. 1983. Silage fermentation of fish and fish waste products with lactic acid bacteria. Journal of the Science of Food and Agriculture 34: 10571067.

Mackie, J. M., Hardey, R. \& Hobbs, G. (eds.) 1971.
Fermented fish products. FAO Fisheries Reports, No. $100,54 \mathrm{p}$.

Partanen, K., Alaviuhkola, T. \& Näsi, M. 1992. Ensiled slaughter offal as protein source for growing pigs. Agricultural Science in Finland 1: 547-556.

Raa, J. 1980. Biochemistry of microbial fish spoilage and preservation by lactic acid bacteria and added acid. In: Emejuavie, S. O. et al. (eds.). Global Impacts of Applied Microbiology. Sixth International Conference, Congress Proceedings Lagos, Nigeria. p. 3-17.

Raccach, M. \& Baker, R. C. 1978. Lactic acid bacteria as an antispoilage and safety factor in cooked, mechanically deboned poultry meat. Journal of Food Protection 41: 703-705.

Russel, S. M, Fletcher, D. I. \& Merca, W. C. 1992. Lactic acid fermentation of broiler processing waste; physical properties and chemical analyses. Poultry Science 71: 765-770.

SAS 1985. SAS/STAT® User's Guide: Statistics, Version 5 Edition. SAS Institute Inc. Cary, NC. 956 p.

Shewan, J. M. 1977. The bacteriology of fresh and spoiling fish and the biochemical changes induced by bacterial action. In: Procedings of the conference on handling, processing and marketing of tropical fish. Tropical Products Institute London. p. 51-66.

Skrede, A. \& Nes, I. F. 1988 . Slaughterhouse by-products preserved by Lactobacillus plantarum fermentation as feed for mink and foxes. Animal Feed Science and Technology 20: 287-298.

Smith, J. L. \& Palumbo, S. A. 1981. Microorganisms as food additives. Journal of Food Protection 44: 936-955 Tibbets, G. W., Seerley, R. W. \& McCampell, H. C. 1987. Poultry offal ensiled with Lactobacillus acidophilus for growing and finishing swine diets. Journal of Animal Science 64: 182-190.

Tramer, J. 1966. Inhibiting effect of Lactobacillus acidophilus. Nature (London) 211: 204-205.

Urlings, H. A. P. 1992. Fermentation of animal by-products. Microbiological aspects of processing, epidemiology and animal nutrition. Diss. Utrecht University, Faculty of Veterinary Medicine, Department of the Science of Food of Animal Origin, Utrecht, The Netherlands. 135 p. Wirth, F. \& Leistner, L. 1970. Redoxpotentiale in Fleischkonserven. Fleischwirtschaft 50: 491-492.

Wolstrup, J. 1972. Mikrobiologiske undersøgelser af vomindholdet fra køer fodret med sukkerroer, græsensilage, hø og græs. Thesis. Mikrobiologisk Laboratorium, Royal Veterinary and Agricultural University, Denmark. $47 \mathrm{p}$.

Wooley, R. E., Gilbert, T. P., Whitehead, W. K., Shotts, E. B. Jr. \& Dobbins, C. N. 1981. Survival of viruses in fermented edible waste material. American Journal of Veterinary Research 42: 87-90. 


\title{
AGRICULTURAL SCIENCE IN FINLAND
}

Lassén, T. M.: Lactic acid fermentation of fish offal and chicken by-product with different starter cultures

\section{SELOSTUS}

\section{Kala- ja kanajätteiden maitohappofermentaatio erilaisilla mikrobiviljelmillä}

\author{
T. Mikael Lassén \\ Royal Veterinary and Agricultural University, Tanska
}

Tutkimuksessa selvitettiin, soveltuuko maitohappofermentaatio kala- ja kanajätteiden säilömismenetelmäksi. Sillin (Clupea harengus) jätteet (sisälmykset ja päät) ja kanajätteet (päät, sisälmykset, höyhenet, jalat ja hylätyt kokonaiset kanat) hienonnettiin, sekoitettiin $5 \%$ :een dekstroosiin ja siirrostettiin neljään erilaiseen $10^{8} \mathrm{cfu} / \mathrm{g}$ maitohappobakteeriviljelmään. Tätä sivutuotetta fermentoitiin $25^{\circ} \mathrm{C}$ lämpötilassa. $\mathrm{pH}$, maitohappopitoisuus \%, redox-potenti- aali ja haju tutkittin neljän viikon varastointiaikana. Sillijätteen pH laski 6,8:sta 4,2:een viikossa ja vakiintui 4,3 :een. Samanaikaisesti maitohappopitoisuus oli $2,0 \%-3,2 \%$ ja pitoisuudet vakiintuivat $2,5 \%$ :sta 4,0 \%:iin. Kanajätteen pH laski ja vakiintui 4,4:ään, ja maitohappopitoisuus oli 3,2 \% viikon fermentaation jälkeen. Sekä silli- että kanajätteellä oli negatiivinen ja vakaa redox-potentiaali viikon fermentaation jälkeen. 